Tema: Tillid

\title{
Om tillid, mistillid og professionsetik
}

Hans Fink, docent emeritus, Institut for Kultur og Samfund, Aarhus Universitet

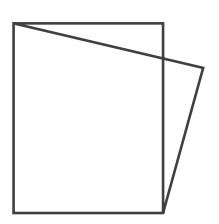

\section{Profession og etik}

Når man er aktiv i en profession, kan man ikke være ligeglad med, hvordan ens fagfæller udøver deres faglige virksomhed. Det falder på en måde tilbage på alle i professionen, hvis enkelte gør deres arbejde dårligt, fusker med det eller direkte snyder og bedrager dem, der har stolet på deres kompetence og faglige hæderlighed. Som fagperson er man dybt afhængig af sine klienters individuelle og samfundets kollektive tillid, og begge dele kan lide skade, når nogle i professionen svigter; også hvis man selv prøver at holde en høj faglig etos. Så længe der har været faglig selvorganisering, er der derfor blevet gjort forsøg på at sikre faglige minimumsstandarder og at opretholde en vis selvjustits, så man kan sanktionere "brådne kar" og "sorte får" også i tilfælde, der ikke falder ind under den almindelige lovgivning. Lægernes hippokratiske ed fra den græske oldtid er blandt de ældste forsøg på faglig selvregulering, og allerede i middelalderens håndværkerlav blev det sat gennemgribende i system.

Siden 1980'erne har der været en bred kulturel bølge i hele den vestlige verden, som man kunne kalde etikbølgen'. 'Etik' er gået fra at være et sjældent brugt fremmedord, der først og fremmest var navnet på en akademisk disciplin i filosofi- og teologistudierne, til at indgå i navnet på en lang række råd, nævn, komiteer og udvalg, ikke mindst, men heller ikke udelukkende på sundhedsområdet, for så derfra at glide ind i daglig- 
Om tillid, mistillid og professionsetik

sproget, sådan at man nu kan tale om, at en opførsel er uetisk, hvor man før ville have sagt umoralsk eller bare forkert. Ordet 'uetisk' findes slet ikke i Ordbog over det danske sprog, bind 25 fra 1950. Nu kan det indgå i en gradbøjning som jeg engang hørte i radioen: "Det er ikke bare umoralsk; det er uetisk; ja, det er direkte ulækkert".

Etikbølgen har også medført en kraftig intensivering af den professionelle selvregulering og nu for første gang under overskriften professionsetik. Stort set alle professioner har vedtaget retningslinjer for god faglig praksis og nedsat organer, der skal udbrede kendskabet til disse regler, overvåge, at de overholdes, og behandle klager, når de brydes. Hidtil uskrevne regler nedskrives, og quasi-juridiske institutioner oprettes for at holde orden $\mathrm{i}$ eget hus uden nødvendigvis at involvere domstolene. Advokatnævnet overvåger advokatetiske regler, Foreningen af danske revisorer håndhæver revisoretiske regler, Dansk sygeplejeråd har sygeplejeetiske retningslinjer, og DBFU - Dansk Bilforhandler Union - er en brancheforening for seriøse brugtvognsforhandlere, der ifølge deres egen hjemmeside "jævnligt siger nej tak til forhandlere, der ikke kan eller vil opfylde foreningens krav omkring salgsbetingelser, moral, etik og generel forretningsførelse". Tatovørfaget har foreløbigt ikke kunnet finde ud af at organisere sig og kan nu vente mere detaljeret lovgivning til beskyttelse af "klienterne".

Også på uddannelses- og forskningsinstitutionernes område er der sket en etisk oprustning ${ }^{2}$. Udvalgene Vedrørende Videnskabelig Uredelighed (UVVU) blev oprettet i 1993, først kun på det sundhedsvidenskabelige område, men fra 1998 på alle videnskabelige områder. Ordningen er blevet ændret undervejs og er for tiden igen til revision. I mellemtiden har Uddannelses- og Forskningsministeriet sammen med Danske Universiteter i 2015 udsendt en ny Kodeks for integritet i forskning, der skal være med til at sikre troværdighed i dansk forskning, og mange universiteter har vedtaget deres egne regler for Responsible Conduct of Research (RCR). European Science Foundation (ESF) og All European Academies (ALLEA) har vedtaget The European Code of Conduct for Research Integrity, og på verdensplan er der vedtaget det såkaldte Singapore Statement on Research Integrity. Al denne aktivitet er ikke mindst foranlediget af en række skandalesager, hvor prominente forskere er blevet taget i eller beskyldt for at snyde med deres resultater. Her hjemme har den store opmærksomhed omkring Lomborgsagen og Penkowasagen i høj grad været en motiverende faktor. Det spiller givetvis også ind, at først den amerikanske Medical Science Foundation og derefter The European Science Foundation har gjort det til en betingelse for at modtage forskningsbevillinger, at det universitet, forskerne kommer fra, har vedtaget regler for forskningsintegritet, giver undervisning i god forskningsskik på alle niveauer i uddannelserne og har etablerede procedurer for behandling af klager over videnskabelig uredelighed. Det er ikke tilstrækkeligt med nationale regler; det enkelte universitet skal selv vise, at det har vilje og evne til at leve op til kravene.

Alle disse regler understreger, at man som forsker ikke må snyde og bedrage, ikke lade sig bestikke, ikke stjæle andres arbejde og ikke unødigt skade det, man forsker i. Det er alt sammen noget, som burde være en selvfølge. At have videnskabelig forskning som profession er at have nysgerrighed og hæderlighed som profession. Der har dog altid været nogle, der er faldet for fristelsen til for karrierens, ærens eller pengenes skyld at skyde genveje, og den voldsomme vækst i antallet af forskere og forskningsmidler har gjort det påtrængende at eksplicitere principper, som før kunne anses for at være indbygget i forskningens etos og tages for givet som "too obvious for words". Når principperne søges ekspliciteret opdager man dog hurtigt gråzoner, hvor præciseringer i høj kan være på deres plads. Den øgede opmærksomhed om forskningsetik og de nye kontrolorganer kan således med stor rimelighed begrundes i nødvendigheden af at stå vagt om tilliden til videnskaben, forskningen og universiteterne. Hvis den svækkes, er der meget mere på spil end universiteternes økonomi. Samtidigt er der dog også nogle dilemmaer indbygget i en sådan institutionalisering af det etiske. Kontrol er kun bedre end tillid, hvis man kan have tillid til kontrollanterne, og nogle af de langstrakte og komplicerede sager om videnskabelig uredelighed kan måske i sig selv være med til at undergrave offentlighedens tillid til videnskaben.

I alle professioner er der vigtige og meget komplicerede spørgsmål om balancen mellem kontrol og tillid, og om hvordan den statslige kontrol/tillid, spiller sammen med den lokale ledelses kontrol/tillid, klienternes kontrol/tillid og de professionelles selvkontrol/selvtillid. Det skal jeg vende kort og meget selektivt tilbage til afslutningsvis, men i øvrigt blot lade være anledning til at fokusere på den tillid, som alle former for professionsetik og forskningsetik sigter på at værne om - den tillid som er emnet for dette temanummer. Det vil jeg gøre ved ud fra min egen faglighed 
Tema: Tillid

at tage udgangspunkt i begrebet tillid og de ord, vi bruger til at tænke og tale om tillid. I mit professionelle arbejde som begrebsanalytiker har jeg gjort mig det til vane at begynde med at belyse vores begrebsanvendelse etymologisk. Det kan aldrig give direkte svar på aktuelle problemer, men det kan skabe en nyttig distance til måden, vi ofte ganske ureflekteret formulerer dem på, og det kan være med til at ridse et begrebsmæssigt landskab op, hvor man i bedste fald kan se oplysende sammenhænge, som kan hjælpe os til at formulere vores problemer rigtigere og mere frugtbart. Jeg vil derfor i det følgende prøve at lade nogle sproglige betragtninger belyse tillid og mistillid for så at vende kort tilbage til professionsetikken.

\section{Tillidsbegrebets rødder}

At have tillid til noget er at sætte sin lid til det og at fæste lid til det. Men hvad er "lid" for noget? Det man sætter sin lid til, går man ud fra er på-lide-ligt - til at lide på. "Det kan du lide på", kunne man sige i gamle dage. Nogle af os har som børn lært, at pigerne udi Spanien danser polka så let på tå, men at de desværre ikke er til at lide på. Men hvad er det at kunne lide på noget eller at være til at lide på? Verbet 'at lide' er nært beslægtet med verbet 'at læne'. Det man kan lide på, og det man kan sætte sin lid til, er det man kan læne sig til. Tillid taler vi om i sammenhænge, hvor man risikerer at miste balancen, hvis man ikke har noget at læne sig til. Det man læner sig til, forventer man bevidst eller ubevidst vil kunne give én den støtte, man har brug for, og være så tilpas stabilt og bestandigt, at det er til at regne med et kortere eller længere stykke ind i fremtiden. At have tillid til noget er at læne sig til det i forventning om og tiltro til at det ikke vil svigte.
Både 'lide' og 'læne' (og engelsk: 'lean' og tysk: 'lehnen') kommer af den indoeuropæiske rod *KLEI(D), som betød sådan noget som at læne eller hælde. (Herfra har vi også 'en li': en skråning, og det gammeldags udtryk at det lider mod aften). Det er roden til græsk: 'klinein', at bøje, at læne, at vende sig, og til latin: -clinare, at bøje, at hælde. Det er herfra vi har fremmedord som 'deklination', bøjning, 'inklination', tilbøjelighed eller buk, og 'klient', en der læner sig til en anden og sætter sin lid til denne som velgører eller rådgiver.

At have tillid er altid at turde løbe en risiko. Tillid kræver mod eller er en slags mod. Man står og falder med, om det, man har tillid til, lever op til de forventninger, man har til det. Det, man har tillid til, er man, eller gør man sig, afhængig af i en bestemt henseende. Det er denne kobling K.E. Løgstrup udnytter, når han i første kapitel af Den etiske fordring via en analyse af tillid kommer frem til den omfattende gensidige afhængighed, vi som mennesker lever $i$, og det ansvar vi har for ikke at svigte hinandens tillid. Denne kobling er tydeligere i de nordiske sprog end i engelsk, tysk og fransk, hvor de ord, vi oversætter med 'tillid', ikke på samme måde er sprogligt knyttet sammen med det at læne sig til noget. Før vi kommer til disse udenlandske ord, kan vi lige notere os, at vi på dansk kobler det at have tillid med det at stole på; et udtryk som heller ikke har direkte paralleller i engelsk, tysk og fransk. Det betød oprindeligt at anbringe (sig) på en stol. Ordet 'stol' har samme rod som ordet 'stå' og betegner noget opretstående og fast, som man kan lade bære ens vægt (i tillid til at det ikke vil bryde sammen under en). Også her er der tale om en altid risikofyldt afhængighed af fastheden i noget, man støtter sig på.
Roden er *STA, at stå. Det er roden til en lang række ord både i de germanske og de romanske sprog, herunder ordene 'stabil' og 'bestandig'. I denne artikels sammenhæng kan der være grund til at fremhæve, at det er roden til andet led i det græske ord: 'episteme', viden og derfra fremmedordet 'epistemologi', læren om viden, den erkendelse, der står fast, og er til at stole på. Måske er det også relevant, at det er roden til ordet 'stat', egentlig en tilstand, der står fast. (En forbindelse som selve ideen om en konkurrencestat sætter spørgsmålstegn ved med en vis utryghed til følge). Det engelske 'trust' og de tyske 'Vertrauen' og 'Zutrauen' kommer af den indoeuropæiske rod *DERU eller *DREU, som betød sådan noget som hård, fast og solid. På græsk er det roden til 'dendron', træ, træstamme og til 'drus', eg (en særligt hård træsort). På latin er det roden til 'durus', hård og 'durare', gøre hård, vedblive, vedvare, bestå. På engelsk er det ud over 'trust' også roden til både ordet 'tree', træ og ordene 'true', sand og 'truth' sandhed. Det sande er det faste, der står fast, og som derfor vil være til at læne sig op ad, regne med og stole på. På tysk er det ud over 'Vertrauen' og 'Zutrauen' roden til ordet 'treu', trofast, og 'Treue' troskab. På dansk har vi herfra ordene: 'træ', 'tro', 'trofast' og 'tryg'. Tryghed er den følelse, man har, når man kan hvile i tilliden til sine omgivelser. Grundassociationen er fasthed, men der er tale om en karakteristisk dobbelthed af objektiv og subjektiv fasthed; både træets fasthed og troens fasthed, både den forventede fasthed og fastheden $i$ forventningen, både det tillidsværdiges fasthed og den tillidsfuldes fasthed. Momentet af risiko og objektiv afhængighed er her ikke så tydeligt som ved 'tillid', og det subjektive og bevidste moment af 


\section{At have tillid til noget er at læne sig til det $\mathbf{i}$ forventning om og tiltro til, at det ikke vil svigte.}

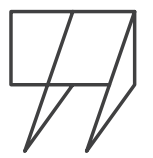

fastholden til gengæld tydeligere. Hertil kommer de forskelle, der giver sig af, at 'trust' (og 'tro' og sammensætningerne med '-trauen') kan bruges både som substantiv og som verbum, mens 'tillid' kun kan bruges som substantiv (og 'stole på' kun som verbum). Det er klart nok, hvorfor vi kan oversætte de engelske og tyske ord med 'tillid'; men også klart, at der er nuanceforskelle, som kan spille ind, f.eks. når man som dansker forholder sig til den internationale tematisering af tillid som social kapital med udgangspunkt i det engelske 'trust'. Når der på amerikanske dollar sedler står: "In God we trust", ville det ikke være helt det samme, hvis der på danske hundredkronesedler stod "I tillid til Gud" eller "Vi stoler på Gud".

Det franske 'confience' (og det engelske 'confidence') bringer så igen lidt andre associationer i spil. Sidste del af disse ord kommer af den indoeuropæiske rod *BHEID, der betød noget i retning af sikker forvisning. Det er også roden til græsk: 'pistis', tro, tiltro, tillid. På latin er det roden til 'fidere', at have tillid til, stole på, og 'fides', tro, tiltro, tillid, og til 'foedus', pagt, overenskomst. På engelsk er det også roden til 'faith', tro og til 'federation', sammenslutning, aftale om trofasthed. Disse latinske ord har stået helt centralt i udviklingen af både den kristne teologi og den tidlige aftaleret. De nærmeste slægtninge i de germanske sprog er f.eks. dansk: 'bie', vente tålmodigt, engelsk: 'bide' forblive, afvente og 'abide', stå ved (et løfte), holde stand, udholde. Her er den subjektive, mentale side af fastholden nærmest enerådende. Der er ingen stærk kobling hverken til objektiv fasthed eller til risiko og afhængighed, selv om det igen er klart, at 'confience' og 'confidence' kan oversættes med 'trust', 'Vertrauen' og 'tillid'.

\section{Tillid og mistillid}

Med 'læne', 'fast' og 'vente' som stikord kan man se tillid som en fast, men ikke ganske urokkelig, forventning om, at nogen eller noget vil vise sig at være fast nok til at læne sig til og dermed være eller gøre sig afhængig af for bestemte formåls skyld i en altid risikofyldt fremtid. Det, man har tillid til, kan være noget meget forskelligt: At et andet menneske vil gøre noget for én her og nu, at en ting vil være brugbar for ens formål, at en samfundsinstitution udfylder sin funktion, at ens egne evner slår til i det korte og det lange løb, at den anden vil være der for én, uanset hvad der sker. Tillid er på spil i alle forhold mellem mennesker og er en afgørende komponent i venskab og kærlighed. En vis selvtillid er forudsat i al tillid. At have mod på livet er en omfattende tillid til, at der vil være noget at læne sig til, når der er brug for det. Tillid er således forstået en forventning om, at det, man har forventning til, vil indfri ens forventninger. Tillid kan ikke isoleres som en selvstændig forventning, men er så at sige en almen og ofte implicit forventning indeholdt i enhver mere specifik forventning om noget bestemt. Når man spørger om vej, forventer man svar på, hvordan man når sit mål. Det gør man i tillid til - i en tavs forventning om - at den, man spørger, er én man kan læne sig til, én som vil give relevant og velbegrundet vejledning. Det er en elementær og umiddelbar form for tillid. Man kan udtrykke denne tillid ved at sige til sig selv eller andre, at man 


\section{Vi begynder først at tale om tillid, når tvivlen på en eller anden måde har meldt sig og skal tilbagevises.}

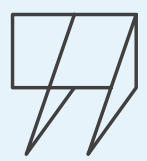

har tillid til vejlederen, at han eller hun virker pålidelig. Men den udtrykte tillid er ikke længere elementær og umiddelbar. Vi begynder først at tale om tillid, når tvivlen på en eller anden måde har meldt sig og skal tilbagevises. "Jeg har fuld tillid til dig" og "Du må stole på mig" siger vi kun, når der er noget, som har givet eller kunne give anledning til mistillid. Somme tider skaber et ord det, det nævner; men ordet 'tillid' skaber snarere sin modsætning. Den elementære tillid hviler man trygt i, den udtrykte tillid besværger en utryghed. Den elementære tillid kan man tematisere og tale om i filosofiske, psykologiske og sociologiske sammenhænge som her, men i dagliglivet er den altid uudtalt og ubegrundet. Den udtrykte tillid er mistillidens modstykke og kræver ligesom denne en begrundelse, nemlig en afvisning af begrundelserne for mistillid.

Det er den udtrykte tillid, Hegel taler om, når han i en tilføjelse til sin Retsfilosofi § 147 siger: "Tro (Glaube) og tillid (Zutrauen) falder under den begyndende refleksion". En hedning tror ikke på en hedensk religion. Der er for hedningen slet ikke noget spørgsmål om tro eller ikke tro. Tilsvarende er der for den tavse tillid slet ikke noget spørgsmål om tillid eller mistillid. Når Løgstrup taler om: "Tilliden som i elementær forstand hører menneskets tilværelse til"3 er det en tavs tillid, den tillid der ligger forud for den begyndende refleksion, han taler om. Hegel ville måske hævde, at der slet ikke kan være tale om tillid på det niveau, men jeg mener, Løgstrup har ret i, at den reflekterede og artikulerede tillid forudsætter en elementær og tavs tillid. I voksne menneskers liv er denne på en måde altid overhalet af refleksionen, men hvis vi benægter, at der (også for den voksne) er tillid før refleksionen, bliver det uforståeligt, hvordan tillid overhovedet kan fremkomme; den kan i hvert fald ikke frembringes ved refleksion. Hegel har ret i, at vi først får anledning til at bruge begrebet tillid, når tvivlen har meldt sig, men vi er så at sige nødt til at tilbagedatere begrebets anvendelsesbetingelser til tilstanden før tvivlen. En snert af mistillid er nødvendig for at erkende tilliden som tillid, men tilliden må have været der, før den kan erkendes, og det kan den først netop i det punkt, hvor den truer med at gå tabt. Den elementære tillid er ontologisk primær, men mistilliden er epistemisk primær. Vores som regel forbeholdne og reserverede tillid må have sit udgangspunkt i indsnævringen eller forskydningen af en uforbeholden tillid, ellers bliver den uforståelig.

Tillid har således en dobbeltstruktur. Vi forstår ikke tillid, hvis vi sammenblander umiddelbar og reflekteret tillid, og vi kan ikke nøjes med en af delene. Man kan forklare, hvorledes mistillid opstår, når den tavse tillid svigtes, og hvorledes den reflekterede tillid opstår som en annullering eller inddæmning af mistillid, men man kan ikke tilsvarende forklare, hvorledes den elementære tillid opstår. Hvis den er der, er den der af sig selv. Vi kan love hinanden troskab, men vi kan ikke love hinanden tillid. Vi kan kræve troskab af hinanden, men vi kan ikke kræve tillid af hinanden. Tilliden står ikke til disposition og kan ikke manipuleres. Vi kan derfor heller ikke gøre os fortjent til 
Om tillid, mistillid og professionsetik

tillid, men vi kan altid prøve ikke at gøre os fortjent til mistillid.

Den elementære tillid ligger i selve det, at liv leves i forventning om, at livsudfoldelsen lykkes, og at forudsætningerne herfor vil være til stede. Man kan ikke handle uden at gøre det i forventning om, at handlingens mulighedsbetingelser vil være opfyldte. Man kan ikke henvende sig til en anden uden at forvente relevante svar. Men vores liv er en risiko, og meget kan gå galt, så vores tavse forventninger skuffes eller endog udnyttes mod os. Tillid er en slags risikovillighed, men man kan miste tilliden eller direkte få mistillid til det, man ellers var parat til at stole på. Man kan miste tilliden til sin vejleder, hvis han eller hun virker usikker, eller hvis vejledningen fører én på afveje og måske slet ikke passer med landskabet, når det kommer til stykket. Man kan få mistillid til vejlederen, hvis noget tyder på, at han eller hun er ude på, eller allerede har, vildledt én. En tillidsvækkende vejleder, som ikke er tillidsværdig, er meget værre end en vejleder, som ikke vækker tillid. Hvis man vil undgå skuffelser, er det helt nødvendigt at gøre sin tillid forbeholden og reserveret. Man må opøve en sund skepsis og en kritisk sans over for denne verdens vejledere og i givet fald kontrollere dem; men man kommer slet ingen vegne, hvis man ikke tør søge vejledning. Man skal lære ikke at være naiv og godtroende, men hvis man prøver at gardere sig hele vejen rundt og nøjes med at have tillid til sig selv, medfører det uvægerligt en forfrossen og livsfjendtlig isolation.

Hvis ens elementære tillid igen og igen er blevet skuffet kan mistilliden til andre blive meget omfattende og invaliderende. Det kan ske i dysfunktionelle familier, i samfund med udbredt kriminalitet og korruption, under krige og ikke mindst borgerkrige. Mistillid kan sætte sig i den enkelte som et selvforsvarsberedskab, en mistillid til alt og alle. Man kan komme til at føle, at man kun har sig selv at stole på, og at man måske ikke engang selv er særligt stabil. Man kan næsten glemme den erfaring med, at andre har været der for én, som ingen kan have overlevet uden. Selv den mest omfattende mistillid har dog den elementære tillid som baggrund. Bristet tillid kan ganske vist ikke genetableres ved en bevidst beslutning, og man kan ikke vælge at lægge mistilliden bag sig, men underligt nok kan den elementære tillid altid melde sig så at sige bag om ryggen på én selv, hvis man bliver optaget af en fælles sag. Det bedste, man kan gøre for sig selv og andre, er at give den ligefremme tillid én chance for at sætte sig igennem ved ikke at kvæle den på forhånd.

\section{Tilliden til de professionelle og de professionelles tillid}

Hvilken betydning har alt dette for professionsetikken? Klienter læner sig til de professionelle i tillid til deres ekspertise og vilje til at hjælpe. Hvis klienterne ikke har tillid, er de umulige at hjælpe, og det faglige arbejde bliver derefter. De professionelle læner sig på den måde til klienternes tillid. Hvis en profession har mange utilfredse klienter, og hvis nogle professionelle bliver taget $\mathrm{i}$ at svigte eller udnytte deres klienters tillid, kan hele professionen komme i offentlighedens søgelys, og reguleringen af det faglige arbejde kan blive strammet. Selv nok så mange tillidsskabende foranstaltninger genskaber dog ikke tilliden, og skærpet kontrol kan i sig selv undergrave både de professionelles faglige selvtillid og muligheden for tillidsfuld kontakt til klienterne.
Det er vigtigt for alle parter, at der er tillid til professionerne, men det nytter aldrig at fokusere direkte på at styrke andres tillid. Det bedste, de professionelle kan gøre, er at lade en elementær tillid få lov til at indfinde sig af sig selv ved selv at vise tillid og undgå at give anledning til mistillid. Det kan støttes, men ikke sikres, ved udviklingen af et etisk regelsæt for det faglige arbejde; men her er det helt afgørende, at sådanne regler ikke opfattes som udefra kommende krav. Etik er oprindeligt læren om den rette etos, den rette holdning til det og dem, man har med at gøre. For professionelle er den rette etos først og fremmest viljen til saglighed ${ }^{4}$, en ensidig optagethed af den foreliggende opgave, som i forholdet til klienter altid er hensynet til deres bedste. Det faglige arbejde indebærer uvægerligt at mange andre hensyn, f.eks. til arbejdstilrettelæggelse, karriere og indtjeningsmuligheder, men hver gang sådanne hensyn sættes over hensynet til klienternes bedste, svigter man egentlig sine klienters, sine fagfællers og offentlighedens tillid.

Undervisning i professionsetik vil givetvis i stigende grad komme til at indgå i professionsuddannelserne i de kommende år. Man kan håbe, at en høj faglig etos præger undervisningen $i$ alle fag, men det vil være nødvendigt med nogle moduler, hvor der stilles skarpt på gældende regelsæt og de ansvars- og værdimæssige dimensioner i det faglige arbejde, gerne med udgangspunkt $\mathrm{i}$ konkrete "cases". Ikke mindst er det dog vigtigt, at undervisningen støtter, at den enkelte studerende udvikler en åben, faglig og personlig selvtillid uden skråsikkerhed. Det er den første betingelse for at kunne modstå fristelsen til at være mindre end tillidsværdig. 
Tema: Tillid

\section{ENDNOTES}

1 Jeg har behandlet etikbølgen mere udførligt i artiklen "Epokens etik" i min Filosofiske udspil, Aarhus (Philosophia) 2012.

2 Jeg har skrevet nærmere om det i "Universitetsfagenes etik" i Hans Fink et al.: Universitet og videnskab, København (Hans Reitzel) 2003.

3 K.E. Løgstrup: Den etiske fordring, Aarhus (Klim) 2012 (1956) p. 17. Hele dette afsnit er stærkt påvirket af flere års arbejde med Løgstrups moralfilosofi, men jeg prøver at skrive om det, han skriver om, uden at gøre det ved at skrive om, hvad han skriver om det. Det opfatter jeg som helt i hans ånd.

4 Jeg beskriver forholdet mellem faglighed og saglighed nærmere både i "Universitetsfagenes etik" og i "Filosofi, fagfilosofi og filosofihistorie" i Filosofiske udspil. 